\title{
THE LEARNER AS LEXICOGRAPHER: \\ USING MONOLINGUAL AND BILINGUAL CORPORA TO DEEPEN \\ VOCABULARY KNOWLEDGE
}

\author{
Kristina HMELJAK SANGAWA \\ University of Ljubljana \\ kristina.hmeljak@ff.uni-lj.si
}

\begin{abstract}
Learning vocabulary is one of the most challenging tasks faced by learners with a non-kanji background when learning Japanese as a foreign language. However, learners are often not aware of the range of different aspects of word knowledge they need in order to successfully use Japanese. This includes not only the spoken and written form of a word and its meaning, but also morphological, grammatical, collocational, connotative and pragmatic knowledge as well as knowledge of social constraints to be observed. In this article, we present some background data on the use of dictionaries among students of Japanese at the University of Ljubljana, a selection of resources and a series of exercises developed with the following aims: a) to foster greater awareness of the different aspects of Japanese vocabulary, both from a monolingual and a contrastive perspective, b) to learn about tools and methods that can be applied in different contexts of language learning and language use, and c) to develop strategies for learning new vocabulary, reinforcing knowledge about known vocabulary, and effectively using this knowledge in receptive and productive language tasks.
\end{abstract}

Keywords: vocabulary instruction; Japanese language teaching; dictionary use; corpus use

\section{Povzetek}

Učenje besedišča je ena najbolj zahtevnih nalog pri učenju japonščine kot tujega jezika za študente, ki še ne poznajo kitajskih pismenk. Študenti se pri tem velikokrat ne zavedajo širine nabora informacij o posameznih besedah, ki je potreben za uspešno komuniciranje $v$ japonščini. Za vsako besedo morajo namreč poznati poleg njene pisane in glasovne oblike ter pomena tudi njene oblikoslovne, skladenjske, kolokacijske, konotacijske in pragmatične lastnosti ter družbeno pogojene omejitve pri njeni rabi. V članku predstavimo rezultate ankete o rabi slovarjev med študenti japonščine na Univerzi v Ljubljani ter izbor referenčnih virov in zbirko vaj, ki smo jih sestavili z naslednjimi cilji: a) razviti zavest o različnih vidikih besedišča, tako $z$ enojezičnega kot s kontrastivnega zornega kota; b) spoznati orodja in metode, ki se lahko uporabijo v različnih kontekstih učenja in rabe jezika; c) razviti strategije za učenje novega besedišča, utrjevanje znanega besedišča in za učinkovito rabo tega znanja $v$ pasivnih in aktivnih jezikovnih nalogah.

Ključne besede: učenje besedišča; učenje japonščine kot tujega jezika; raba slovarjev; raba korpusov

Acta Linguistica Asiatica, 4(2), 2014.

ISSN: 2232-3317, http://revije.ff.uni-lj.si/ala/

DOI: 10.4312/ala.4.2.53-65 


\section{Introduction}

Learning vocabulary is one of the most challenging tasks faced by learners with a non-kanji background when learning Japanese as a foreign language. Most learners are well aware of the quantitative dimension of this task from the beginning and soon develop or try to develop strategies to memorise large quantities of words and kanji characters. However, they are often not equally aware of the qualitative dimension of vocabulary and of the range of different aspects of word knowledge they need in order to successfully use Japanese. This includes not only the spoken and written form of a word and its meaning, but also morphological, grammatical, collocational, connotative and pragmatic knowledge as well as knowledge of social constraints to be observed.

In the following sections, we present some background data on the use of dictionaries among students of Japanese at the University of Ljubljana, gleaned from a small-scale questionnaire survey and from informal observations in class.

We then present a selection of resources and a series of exercises developed with the following aims: a) to foster greater awareness of the different aspects of Japanese vocabulary, both from a monolingual and a contrastive perspective, b) to learn about tools and methods that can be applied in different contexts of language learning and language use, and c) to develop strategies for learning new vocabulary, reinforcing knowledge about known vocabulary, and effectively using this knowledge in receptive and productive language tasks.

\section{Background: dictionary use among Japanese language students}

In order to investigate how students approach vocabulary learning, in the spring of 2013 we conducted a small-scale questionnaire on the use of reference resources (dictionaries, internet sites, mobile applications etc.) among students of Japanese in their second and third year of study at the University of Ljubljana. We found that students very often do use dictionaries and other resources during their study, but are not particularly selective when choosing which dictionary to use, and mostly look up only the most basic information.

While all of the 17 students surveyed reported that they use on-line dictionaries, only one reported having and using a dictionary in book form (Hadamitsky \& Spahn 1982, a reference book of very small size) to look up the readings and stroke order of unknown characters. Six students reported having and using portable electronic dictionaries (Sharp and Casio, produced for the Japanese market) to look up JapaneseEnglish or English-Japanese translations and unknown kanji characters.

All students reported they use on-line free dictionaries. The dictionaries and other on-line resources mentioned by students are shown in Table 1 . 
Table 1: On-line resources used by Japanese language students at the University of Ljubljana.

\begin{tabular}{lll} 
Type of resource & Resource name & $\begin{array}{l}\text { no. of } \\
\text { students } \\
\text { (N=17) }\end{array}$ \\
\hline based on & jisho.org & 12 \\
WWWJDIC & tangorin.com & 4 \\
& www.popjisyo.com & 1 \\
& rikaichan & 4 \\
\hline $\begin{array}{l}\text { other } \\
\text { general }\end{array}$ & translate.google.com & 6 \\
resources & jaSlo & 2 \\
\hline kanji & reading tutor (language.tiu.ac.jp) & 1 \\
resources & & \\
& handwritten kanji recognition kanji.sljfaq.org & 2 \\
\hline grammar & kanjialive.com & 1 \\
resources & j-gram (www.jgram.org) & 3 \\
& Natsume & 1 \\
& Maggiesensei.com & 1
\end{tabular}

Most of the dictionaries they mentioned are based on the Japanese-English database produced by the Electronic Dictionary Research and Development Group at Monash University (EDRDG 2014), a dictionary with a very large number of lemmas but only basic information for each lemma (part of speech, translation equivalents, some stylistic labels and a crowdsourced database of usage examples). Twelve out of seventeen students used jisho.org, four used tangorin.com, four used the browser add-on Rikaichan, and one used popjisyo.com; four of the students reported using two of these, although they are only different interfaces to the same Japanese-English database.

Six students reported using the machine-translation site translate.google.com to look up words in several directions (Japanese to English, English to Japanese, Slovene to Japanese), while only two students mentioned other tools. Moreover, 10 out of 17 students reported they use dictionary applications on their mobile phone; some noted the name of the application (four mentioned Kanji recognizer, three mentioned JED, two mentioned WWWJDIC (based on EDRDG), and each of the following was mentioned by one student: All 国語辞典, imiwa (based on EDRDG), Lexiqon and Aedict), while some just answered "a dictionary on my mobile phone".

While it is clear that most students probably use freely available resources because they cannot afford expensive electronic dictionaries, it is rather surprising that none of them mentioned freely available Japanese comprehensive reference sites such as weblio, yahoo jisho, goo jisho or Sanseido's Web Dictionary. When asked about these sites in follow-up interviews, most students responded that they did know about some of these 
sites, but were overwhelmed by the Japanese interface and did not feel comfortable using them.

When asked what they use these dictionaries and tools for, all students reported they look up words (translations) and unknown kanji characters, and eight out of seventeen students reported they look up how words are used in context.

Finally, when asked whether they have any difficulty with these dictionaries and tools, five students reported they do not always find the word they are looking for, three mentioned that translate.google.com is not reliable, three reported they cannot read the Japanese words they find and spend time looking up the readings, two mentioned they are not sure whether the word they find is the right one for what they mean, two reported having problems with their internet connection, and only one mentioned the problem that words and senses (translations) in the on-line dictionaries are not ordered according to frequency. These answers indicate that students tend to use dictionaries and other reference tools to look up translations of single words and character readings, and are mostly concerned with finding translation equivalents, while only some search for contexts of word use, and none apparently look up connotations, stylistic or pragmatic information.

The survey had two limitations. Firstly, the questions were open ended in order not to influence the responces, and it is therefore quite possible that students forgot to mention some of the reference sources and tools they use, or specific information that they look up less frequently. Secondly, the survey did not cover all of our students and is not representative of the whole student population. However, some tendencies were observed that are also reflected in other reports on dictionary use by learners of Japanese (Fukuda \& Hiratsuka 2011, Suzuki 2012, Moroz 2013). Overall, students tend to use simple and freely available reference tools, relying on crowd-sourced Japanese-English and English-Japanese bilingual dictionaries with user- friendly interfaces. They are mostly not aware of other, more sophisticated tools and reference material, and even those students who do know about other resources mostly use them only to look up translations and readings.

On the basis of these results and of similar feedback repeatedly obtained during informal observation in class, we concluded that students need more information on other available reference sources and tools, in order to be able to select the most appropriate tool in each learning situation, and that they require coaching on the use of these tools for specific language learning needs.

\section{Introducing students to different reference resources}

Considering our students' reference habits, we selected a few resources that could better equip them for their learning needs and developed some exercises to help them master the use of these resources. 


\subsection{Dictionaries}

Firstly, since many students are not aware of different freely available resources, we compiled a list of links to on-line dictionaries on the department's e-learning site ${ }^{1}$, including

a) the Japanese-Slovene dictionary $j a S l o^{2}$, compiled at our department (Hmeljak Sangawa \& Erjavec 2012), surprisingly not known to many of the students;

b) different interfaces to WWWJDIC mentioned by students themselves, including $W_{W W J D I C}^{3}$ itself and its popular interfaces: Denshi Jisho ${ }^{4}$ Tangorin $^{5}$ and Popjisyo ${ }^{6}$;

c) Japanese reference sites - dictionary aggregators such as Yahoo! dictionary ${ }^{7}$, goo dictionary ${ }^{8}$, kotobank $^{9}$ and Weblio $^{10}$, all of which include dictionaries by major Japanese publishing houses such as Sanseido, Kodansha, Shogakukan and others;

d) the crowd-sourced Japanese-English dictionary Eijiro ${ }^{11}$,

e) other sites mentioned by students, including Google translate ${ }^{12}$.

This list of on-line reference sources is also presented alongside other resources (textbooks and reference books) during orientation meetings held for each Japanese language class at the beginning of the academic year, where students are encouraged to explore the resources and familiarise themselves with them.

\subsection{Corpora and lexical profiling systems}

The second part of the list of on-line resources includes corpora and lexical profiling systems that can be used by intermediate and advanced students to obtain more detailed information about collocational and stylistic aspects of the words they are learning.

1 Resource list within the departmental bulletin board "Jpn forum" at

[http://e-ucenje.ff.uni-lj.si/mod/page/view.php?id=4426]

2 jaSlo [http://nl.ijs.si/jaslo/cgi/jaslo.pl]

3 WWWJDIC [http://wwwjdic.org/]

4 Denshi Jisho [http://jisho.org/]

5 tangorin [http://tangorin.com/]

6 Popjisyo [http://www.popjisyo.com/]

7 Yahoo!Japan 辞書 [http://dic.yahoo.co.jp/]

8 goo 辞書 [http://dictionary.goo.ne.jp/]

9 kotobank [http://kotobank.jp/]

${ }^{10}$ Weblio [http://www.weblio.jp/]

11 Eijiro 英辞郎 [http://www.alc.co.jp/]

12 google translate [https://translate.google.com/] 
In the last few years, quite a number of Japanese corpora and query systems have been developed, beginning with $B C C W J^{13}$ developed at the NINJAL Center for Corpus Development with the concordancers Shonagon ${ }^{14}$ and Chunagon ${ }^{15}$ (Maekawa et al. 2014); JpWaC, a web corpus deployed within the lexical profiling system Sketch Engine $^{16}$ (Srdanović et al. 2008); its derivative JpWaC-L (Hmeljak Sangawa \& Erjavec 2012), a corpus for learners of Japanese containing extracts from $J p W a C$ ranked according to the five levels of the Japanese Language Proficiency Test specifications (JF \& AIEJ 2004); the Japanese internet corpus and query system ${ }^{17}$ developed at the Centre for Translation studies of the University of Leeds (Sharoff 2006); the writing support system Natsume ${ }^{18}$ developed at Tokyo Institute of Technology, a lexical profiling system covering multiple monolingual Japanese corpora simultaneously (Hodošček \& Nishina 2012); and the lexical profiling system NINJAL-LWP developed by the National Institute for Japanese Language and Linguistics and the Lago Institute of Language, applied to both the $B C C W J^{19}$ (Pardeshi \& Akasegawa 2011) and to the Tsukuba web corpus ${ }^{20}$ (Imai et al. 2013).

Students are also encouraged to use bilingual concordances. In particular, they are introduced to two parallel concordancers. The first is the Japanese-Slovene parallel corpus $j a S l o^{21}$ developed at our department, a corpus of literary, academic and other web-harvested Japanese texts with Slovene translations, amounting to 760,000 Japanese tokens in 132 documents and 530,000 tokens in the corresponding Slovene translations (Hmeljak Sangawa \& Erjavec 2012). The second corpus tool is Linguee $^{22}$, a freely available dictionary combined with a search engine that retrieves translated examples from internet-harvested bilingual texts (Calvert 2009).

\section{Vocabulary exercises}

After being introduced to the resources listed above, students engage in a series of vocabulary exercises and tasks, similar to those described by Frankenberg-Garcia (2012, 2014) and Montero et al. (2014). These were developed with two main aims. The first is to equip students with a knowledge of existing resources, the skills needed to use them, and strategies for choosing the most effective resource in specific situations. The second

\footnotetext{
13 NINJAL Center for Corpus Development [http://www.ninjal.ac.jp/corpus_center/]

14 Shonagon [http://www.kotonoha.gr.jp/shonagon/]

15 Chunagon [http://chunagon.ninjal.ac.jp/]

16 Sketch Engine [http://www.sketchengine.co.uk/]

17 Leeds internet corpora [http://corpus.leeds.ac.uk/internet.html]

18 Nastume writing support system [http://hinoki.ryu.titech.ac.jp/natsume/]

19 NINJAL-LWP for BCCWJ (NLB) [http://nlb.ninjal.ac.jp/]

${ }^{20}$ NINJAL-LWP for TWC (NLT) [http://corpus.tsukuba.ac.jp/]

21 jaSlo parallel corpus [http://nl.ijs.si/noske/jpl2.cgi/first_form]

${ }^{22}$ Linguee [http://www.linguee.com/english-japanese]
} 
is to foster awareness of the different aspects of vocabulary knowledge, while encouraging autonomous learning.

We begin with simple exploratory tasks to introduce students to the use of different resources and interfaces. The first task focuses on dictionaries rather than on corpora, since dictionaries are used by all students and are already familiar to them.

\subsection{Task 1: verifying the source}

Since most students rely on dictionary sites or mobile applications based on the crowd-sourced Japanese-English database produced by EDRDG and are sometimes not even aware of the fact that they are looking up data from the same database using different interfaces, we prepared an exercise to raise their awareness about the structure and content of different dictionary sites, asking them to distinguish between the interface and the data source.

Students are briefly introduced to the dictionaries mentioned in 3.1 and then asked to find and compare dictionary entries for the same word in all dictionary sites.

For example, when they search for the word 留守番, they find that WWWJDIC, Denshi Jisho, Tangorin and Popjisyo provide exactly the same English translations, part of speech information and compound entry, and that even the examples (given only in WWWJDIC and Tangorin) are exactly the same, while only the amount of external links and the layout and colour of the entries are different.

\section{WwWJDIC: Word Display
4
4}

○○留守番【るすばん】 (n,vs) (1) care-taking; house-sitting; house-watching; staying at home; (2) caretaker; house-sitter; (P) [Edit][ViewDB] [V][Ex][L][G][GI][S][A]

(1)その子は留守番をしなければならないと言って怒っていた。 The boy was cross at having to stay at home.[Amend]

\section{○留守番電話【るすばんでんわ】 (n) answering machine; answer phone}

\section{[Edit][ViewDB][Ex][L][G][GI][S][A][W]}

あなたは留守番電話を買うべきだ。You should buy an answering machine.[Amend]

Figure 1: Results for the search string 留守番 in WWJDIC. 
$000 \quad$ Find words - Denshi Jisho

4 + + 辞 http://jisho.org/words?jap=留守番\&eng=\&dict=edict C Q. Google

\begin{tabular}{|c|c|c|}
\hline 留守番 & るすばん & $\begin{array}{l}\text { 1: care-taking; house-sitting; house-watching; } \\
\text { 2: caretaker; house-sitter }\end{array}$ \\
\hline \multicolumn{2}{|c|}{ Common word, Noun, Suru verb } & $\underline{\text { Sentences }} \underline{\text { Kanji details }}$ External links \\
\hline 留守番電話 & るすばんでんわ & answering machine; answer phone \\
\hline Noun & & $\underline{\text { Sentences }} \underline{\text { Kanji details }}$ External links \\
\hline
\end{tabular}

Figure 2: Results for the search string 留守番 in Denshi jisho.

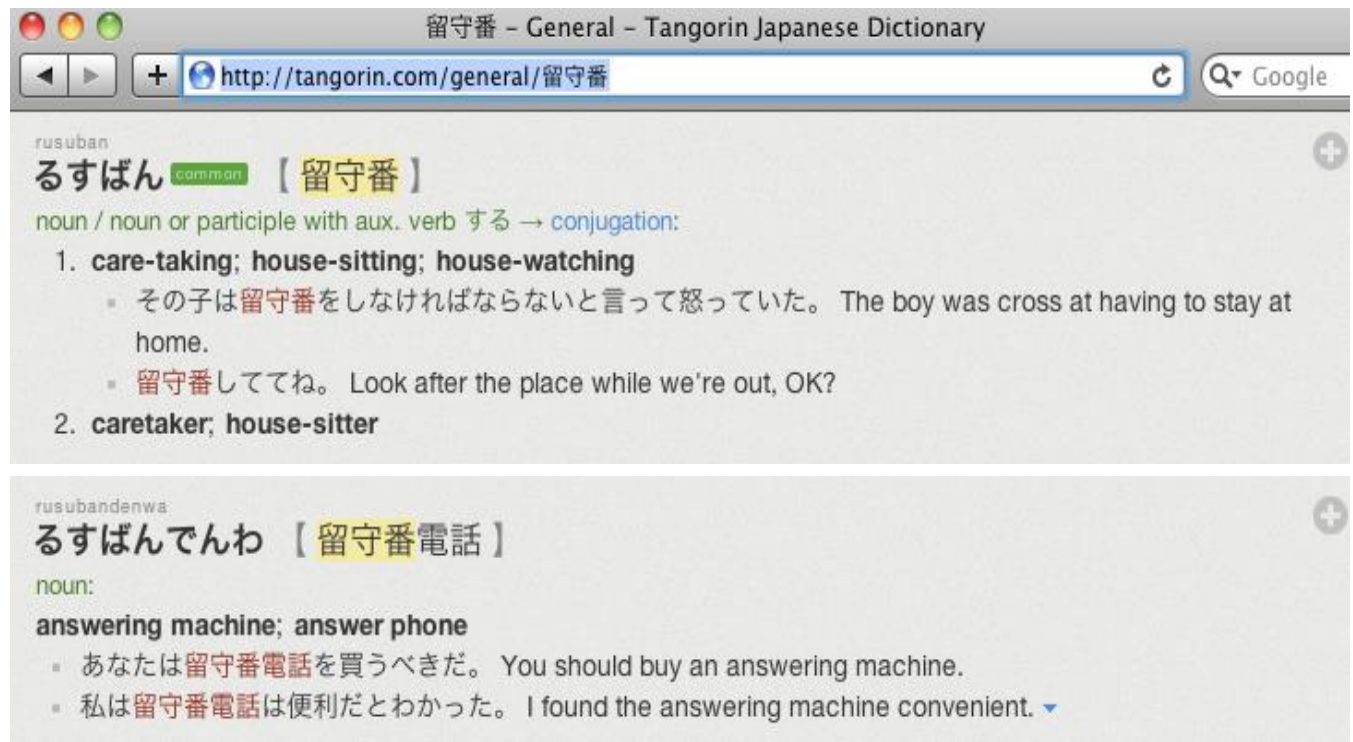

Figure 3: Results for the search string 留守番 in Tangorin. 
POPjisyo.com - Dictionary Translation Japanese/Chinese/K

$4+$ +

留守番 /るすばん：n vs 1 1) care-taking 2) house-sitting

3) house-watching 24) caretaker 5) house-sitter $P$ 留守中 / るすちゅう: n 1) during absence from home 留守 /るす：n vs 11） absence 2) being away from home 2 3) house-sitting 4) house-sitter 35 ) being left unattended to (of one's studies, etc.) 6) neglecting $P$ 留守録 / るすろく：n vs 1) unattended (video, audio) recording

留守宅 / るすたく: n 1) house where the family is out 留守居 / るすい: n vs 1) caretaker or keeper (official post in the Edo era)

留守電/るすでん：n abbr 1) answering machine

2) answerphone

留め男 / とめおとこ : n 1) tout 2) arbitrator

Figure 4: Results for the search string 留守番 in PopJisyo.

Further, they find that the first three of these dictionaries also provide automatically generated links to other dictionaries: WWWJDIC includes links to Google search, Google images, Sanseido dictionary, Eijiro on ALC, example sentences from the Tatoeba project, JapanesePod101.com, Japanese WordNet and Japanese Wikipedia (in the case of 留守番 only six of these links are available); Denshi Jisho offers links to Yahoo! dictionary, goo dictionary and Google search; and Tangorin offers links to Yahoo! dictionary, goo dictionary, Eijiro, Weblio, Linguee, Google Translate, Google.com and Google.co.jp.

On the other hand, they also discover that Eijiro offers the largest number of English translations, examples and compounds, which are different from the other dictionaries, while weblio, Yahoo!dictionary, goo dictionary and kotobank provide similar data from dictionaries that have been published also in book form by traditional dictionary publishing houses.

Finally, we point out to the students the [Edit] and [Amend] buttons in WWWJDIC and check their functioning, to make students aware that entries in this dictionary are often user generated content and sometimes need amending or editing.

With this task, students are encouraged to check the origin of the data they find in on-line reference services, to distinguish between reference data and interfaces, and to choose what works best for them considering both the ease of use and the reliability of the site. 


\subsection{Task 2: matching senses to corpus examples}

This task is aimed at familiarising students with Japanese language corpora, their interfaces and search methods, and to help them discover the difference between dictionary descriptions or translations, which capture the main senses and uses of a word, and examples of word use in corpora, which sometimes deviate from the prototypical uses found in dictionaries. Students are presented with a monolingual dictionary definition of a word with multiple senses and its translations, and instructed to search for the same word in different corpora. Their task is to select five examples from each corpus they consult, as if they were compiling an entry for a learners' dictionary, trying to select examples that are understandable to learners at their own level, and representative of the sense described.

For example, given the following dictionary definitions and translations for the word 運動 (Shogakukan Digital Daijisen 2011, Shogakukan Progressive JapaneseEnglish Dictionary 2012), they matched them with examples such as those given in Table 2.

\begin{tabular}{|c|c|}
\hline source & definition / example \\
\hline Daijisen & $\begin{array}{l}\text { 1. 物が動くこと。物体が時間の経過とともに空間的位置を变え } \\
\text { ること。「振り子の一」「天体一」↔静止。 }\end{array}$ \\
\hline Progressive & 1.〔物体の動き〕 motion; movement \\
\hline $\mathrm{JpWaC}-\mathrm{L}$ & 夢のない人生なんて機械の運動と変わらないじゃないか。 \\
\hline Daijisen & $\begin{array}{l}\text { 2. からだを鍛え、健康を保つために身体を動かすこと。スポー } \\
\text { ツ。「肥満防止のために一する」「一競技」 }\end{array}$ \\
\hline Progressive & $\begin{array}{l}\text { 2.〔体を動かすこと〕 exercise；〔スポーツ〕 sports } \Rightarrow \text { スポーツ; 〔 } \\
\text { 運動競技〕 athletics }\end{array}$ \\
\hline $\mathrm{JpWaC}-\mathrm{L}$ & $\begin{array}{l}\text { 子供さんと遊ぶのはすごい運動ですよ。 } \\
\text { 体にも、心にも準備運動が必要なのである。 } \\
\text { どう考えても、ものを食べて、運動もせずに瘦せられるはずが } \\
\text { ない。 } \\
\text { 普通の運動靴では滑って登れない。 }\end{array}$ \\
\hline Daijisen & $\begin{array}{l}\text { 3. ある目的を達するために活動したり、各方面に働きかけるこ } \\
\text { と。「選挙一」「労働—」「委員になるため一する」 }\end{array}$ \\
\hline Progressive & $\begin{array}{l}\text { 3.〔働きかけ〕 a drive; 〔集団による〕 a movement; 〔特別の目的 } \\
\text { をもつ組織的活動〕 a campaign }\end{array}$ \\
\hline $\mathrm{JpWaC}-\mathrm{L}$ & $\begin{array}{l}\text { 私がいた当時、すでに障害者側から反対運動が起こっていた。 } \\
70 \text { 年代の学生運動の様子が良く分かります。 } \\
\text { これは女性解放運動が望んだものではないであろう。 }\end{array}$ \\
\hline
\end{tabular}

Table 2: Task 3 worksheet - matching dictionary definitions with corpus examples. 
During this task students get acquainted with different corpora interfaces, practice skimming through large amounts of text, become aware of frequent compounds or collocations in which the words are used, and notice how some senses appear more frequently than others.

\subsection{Task 3: comparing dictionary and corpus translations}

The next task is carried out using the Japanese-Slovene parallel corpus jaSlo. Students are again given polysemous words and instructed to search for all possible translations of these words in bilingual corpus examples, in order to compile a bilingual dictionary entry for the given word. During this task they notice how some words (technical terms etc.) are mostly translated with the same equivalent, how polysemous words may have many different translations (e.g. 世話、余裕、無難、etc.), and how some words (人、また、 evidential expressions, onomatopoeia etc.) are sometimes not translated at all. They furthermore explore translations (or omissions) for culturally bound terms (e.g. 就職活動, お酌 etc.), for modal expressions, adverbs (はず、せっか く、やはり、さすが、よほど), and false friends (イメージ*imidž, ドレス *dres, タレント*talent, ユニーク*unikaten, ホステス*hostesa, サービス*servis).

\subsection{Task 4: translating into Japanese}

The last task is again carried out using the Japanese-Slovene parallel corpus jaSlo, but in the opposite direction, searching for all possible translations (or omissions) of Slovene polysemous words, as if to compile a Slovene-Japanese dictionary entry. Distinguishing between Japanese synonyms is very challenging, and students are encouraged to first determine which word or multiword expression in the Japanese examples corresponds to the given Slovene word, and then look up these Japanese words in other corpora and dictionaries.

\section{Feedback and conclusion}

A portion of these exercises was tested in class, and received a mixed response. Overall, students tended to dislike too long exercises and having to browse through long concordance lists. They were frustrated and confused when they had to go through too many steps. The tasks presented above therefore need some refinement and more intermediate tasks, to gradually introduce students to different functions and search methods, with examples that are neither too difficult nor too obvious for the students' level of language competence.

Students responded positively to tasks involving adding or amending content on collaborative sites. Given the scarcity of human and financial resources for the creation of Japanese-Slovene lexicographic resources, a language combination with a very limited number of users and an even more limited number of potential bilingual 
lexicographers, the involvement of Japanese language learners in a guided collaborative Japanese-Slovene dictionary project could produce useful data while at the same time raising students' awareness of the process of dictionary compilation and of the limitations of entries in existing dictionaries.

\section{Literature}

Calvert, David (2009). Tiptoeing towards TBX: strategies for terminology management at a language services provider. Translating and the Computer 31, 19-20 November 2009, London. 14pp. [http://www.mt-archive.info/Aslib-2009-Calvert.pdf]

Electronic Dictionary Research and Development Group (2014). WWWJDIC: Online Japanese Dictionary Service. [http://www.edrdg.org/cgi-bin/wwwjdic/wwwjdic?1C]

Frankenberg-Garcia, Ana (2012). Learners' Use of Corpus Examples, International Journal of Lexicography 25/3. 273-296.

Frankenberg-Garcia, Ana (2014). The use of corpus examples for language comprehension and production, ReCALL 26/. 128-146.

Fukuda, Eriko and Hiratsuka, Mari (2009). Shokyuu gakushuusha ni yoru kanjigo no imi rikai no tame no gaibu risoosu shiyou jittai chousa: denshi jisho no shiyouhou ni shouten o atete. Hokkaidou daigaku ryuugakusei sentaa kiyou 13/58-77. 副田恵理子、平塚真理（ 2009）「初級学習者による漢字語の意味理解のための外部リソース使用実態調査 : 電子辞書の使用法に焦点をあてて」『北海道大学留学生センター紀要』13/58-77. [http://hdl.handle.net/2115/45683]

Fukuda, Eriko aand Hiratsuka, Mari (2011). Nihongo rikai o shien suru gaiteki risoosu no shiyou jittai chousa: shokyuu gakushuusha no hon'yaku tsuuru no shiyou katei ni shouten o atete. Hokkaidou daigaku ryuugakusei sentaa kiyou 15/1-19. 副田恵理子、平塚真理（ 2011）「日本語理解を支援する外的リソースの使用実態調査: 初級学習者の翻訳 ッールの使用過程に焦点をあてて」『北海道大学留学生センタ一紀要』15/1-19.

Hmeljak Sangawa, Kristina and Tomaž Erjavec (2012). JaSlo : integration of a JapaneseSlovene bilingual dictionary with a corpus search system. Acta linguistica asiatica, vol. 2/3, 125-140. [http://revije.ff.uni-lj.si/ala/article/view/223]

Hodošček, Bor and Nishina, Kikuko (2012). Japanese learning support systems: Hinoki project report, Acta Linguistica Asiatica 2/3. 95-123 [http://revije.ff.uni-lj.si/ala/article/view/221]

Imai, Shingo, Shiro Akasegawa, and Prashant Pardeshi (2013). Tsukuba web koopasu kensaku tsuuru NLT no kaihatsu. Dai3kai koopasu nihongogaku workshop yokoushuu. Tokyo:

NINJAL. 199-206. [http://www.ninjal.ac.jp/event/specialists/projectmeeting/files/JCLWorkshop_no3_papers/JCLWorkshop_No3_26.pdf] 今井新悟、赤瀬 側史朗、プラシャント・パルデシ（2013）「筑波ウェッブコーパス検索ッール NLT の開発」『第 3 回コーパス日本語学ワークショップ予稿集』国立国語研究所 199-206.

Japan Foundation, \& Association of International Education Japan (2004). Japanese Language Proficiency Test Content Specifications (Revised ed.). Tokyo: Bonjinsha.

Maekawa, Kikuo, Makoto Yamazaki, Toshinobu Ogiso, Takehiko Maruyama, Hideki Ogura, Wakako Kashino, Hanae Koiso, Masaya Yamaguchi, Makiro Tanaka, and Yasuharu Den (2014). Balanced corpus of contemporary written Japanese, Language Resources and Evaluation 48/2. 345-371 [http://dx.doi.org/10.1007/s10579-013-9261-0] 
Montero Perez, Maribel, Hans Paulussen, Lieve Macken and Piet Desmet (2014). From input to output: the potential of parallel corpora for CALL, Language Resources and Evaluation 48/1. 165-189.

Moroz, Ashley (2013). App Assisted Language Learning: How Students Perceive Japanese Smartphone Apps. Master's Thesis, University of Alberta, Department of Humanities Computing. [http://hdl.handle.net/10402/era.30241]

Pardeshi, Prashant and Shiro Akasegawa (2011). Compilation of basic verbs handbook using the BCCWJ corpus: Salient features and functions of the corpus browsing system NINJAL-LWP. The proceedings of the symposium commemorating the completion of "the Balanced Corpus of Contemporary Written Japanese (BCCWJ)”, 205-216. Tokyo:

National Institute for Japanese Language and Linguistics. パルデシ・プラシャント、赤 瀬川史朗（2011）「BCCWJを活用した基本動詞ハンドブック作成: コーパスブラ ウジングシステム NINJAL-LWP の特徵と機能」『現代書き言葉均衡コーパス（ BCCWJ）完成記念講演会予稿集』国立国語研究所 205-216.

Sharoff, Serge (2006). Creating general-purpose corpora using automated search engine queries. Marco Baroni and Silvia Bernardini (eds.), WaCky! Working papers on the Web as Corpus, Bologna: GEDIT. 63-98. [http://wackybook.sslmit.unibo.it/]

Spahn, Mark and Hadamitsky, Wolfgang (2012). Japanese Kanji \& Kana: A Complete Guide to the Japanese Writing System. Clarendon, VT: Tuttle.

Srdanović-Erjavec, Irena, Tomaž Erjavec, and Adam Kilgarriff (2008). A Web Corpus and Word Sketches for Japanese, Journal of Natural Language Processing - 自然言語処理 15/2. 137-159.

Suzuki, Tomomi (2012). Ryuugakusei no jisho shiyou ni tsuite no jittai chousa - Toukyou gaikokugo daigaku de manabu ryuugakusei e no ankeeto chousa ano kekka to bunseki Investigating dictionary use by foreign students. Toukyou gaikokugo daigaku ryuugakusei nihongo kyouiku sentaa ronshuu 38/1-21. 鈴木智美（2012）「留学生の辞書使用につ いての実態調査一東京外国語大学で学ぶ留学生へのアンケート調査の結果と分析

— Investigating dictionary use by foreign students」『東京外国語大学留学生日本語教 育センター論集』38/1-21 [http://hdl.handle.net/10108/70119] 